File 2796, 43(4) 2nd Print (10)

Avaiable online at www.banglajol.info

Bangladesh J. Sci. Ind. Res. 43(4), 529-536, 2008

BANGLADESH JOURNAL OF SCIENTIFIC AND

INDUSTRIAL RESEARCH

E-mail: bjsir07gmail.com

\title{
Effects of Acid Washing and Additives on Qualities of Waste Lubricating Oil
}

\author{
M. Naimul Haque ${ }^{a}$, M. Yunus Miah ${ }^{b}$, S. Ali Ashruf ${ }^{b}$, \\ M. Rafiqul Islam ${ }^{\mathrm{b}}$ and A. Kumar Das ${ }^{\mathrm{b}}$ \\ ${ }^{a}$ Institute of Fuel Research \& Development, BCSIR, Dhaka-1205 and ${ }^{b}$ Department of Applied \\ Chemistry \& Chemical Technology, University of Dhaka, Bangladesh.
}

\begin{abstract}
:
Waste lubricating oil has been reclaimed by treatment with commercial sulphuric acid followed by adsorption on fuller's earth. A maximum yield (75\%) of reclaimed oil at acid- oil ratio of 10:100 with addition of $10 \%(\mathrm{w} / \mathrm{v})$ fuller's earth has been obtained. Properties of reclaimed oil such as viscosity index, pour point, colour etc. have been improved from 93.4, +2, 5.0 to 109, $-10.5,4.0$ by addition of certain proportion of additives. TGA analysis of waste lubricating oil, reclaimed oil and fresh lubricating oil has also been studied. The reclaimed oil obtained after addition of different types of additives is very comparable to SAE 30 grade lubricating oil in terms of properties and is applicable as a standard lubricant. Such a reuse of waste lubricating oil, in addition to its economic effect will help to reduce environmental problem.
\end{abstract}

Key words : Lubricating oil, TGA analysis, Envirormentl problem and Vscosity index.

\section{Introduction}

Lubricating oil is a valuable and essential product obtained from petroleum fraction. It is used in various production machineries, power plants, automobiles etc. for reducing friction, carrying away heat, protecting against rust $\&$ wear and sealing out contaminant.

The demand of lubricating oil in Bangladesh is increasing day by day. The annual demand is more than 60 thousand MT and this demand is totally met by import at the cost of huge foreign exchange.

Lubricating oil loses its effectiveness after a definite period of use due to contamination. (Guthrie, 1960,; Mynin, et al 2004.) The contaminants which accumulate in the oil and which are responsible for the deterioration of the quality of the oil in use are usually of two kinds such as (a) extraneous impurities and (b) products of oil deterioration. 
Extraneous impurities enter from the surrounding air and from the machine on which the lubricant is being used. These are: dust, dirt, moisture, metallic particles, carbonaceous particles, unburned fuel etc. Products of oil deterioration occur in oils as a result of physical and chemical changes. These are sludge, leaquer, oil soluble and insoluble products etc. These contaminants affect the life and efficiency of the device being lubricated as well as the life of the lubricant.

Waste oil is dangerous to environment. It is estimated that one liter of used oil can contaminate a million liter of surface water. Further, the burning of used oil releases sulphur dioxide, carbon monoxide, lead, zinc etc. into the atmosphere leading to negative effects on wild life and human population (Gomez et al 2004).

In our country a huge quantity of waste lubricating oil is being disposed off causing environmental pollution or partly reused without maintaining the required characteristic properties of the oil which is very harmful for the machineries. Due to the present global oil crisis, the reclamation of waste lubricating oil has come to light and gained special importance among the non-oil producing developing countries like Bangladesh. Thus the reclamation of waste lubricating oil is a welcome step towards conservation of national economy and also to solve disposal and environmental problems.

Studies carried out by the American Petroleum Institute and others (Encyclopedia of Sc. \&Tec, 1966) have established that the conventional reclamation method removes the polynuclear aromatics, heterocyclic compounds containing sulphur, nitrogen and oxygen, asphaltic and resinous materials of waste lubricating oil. It is also reported (Kalichevsky and Kabe, 1956, ; Kovalenko et al, 2007, ; Evstafev,et al, 2004,) that sulfuric acid treatment of waste lubricating oil followed by absorption with fuller's earth also helps improve colour by removing dark colour, which is due to the presence of asphaltic and resinous materials in it.

According to Pidgeon and Tester (Pidgeon and Tester, 1929) lubricating oil used in the crankcases of automobile engines suffer from serious deterioration during use. Among other changes considerable lowering of viscosity indices are observed. Among other properties viscosity index (VI) is the most important of all the properties of lubricating oil. It is a measure of the rate of change of viscosity with temperature. The smaller the change in viscosity with temperature, the higher is the viscosity index and vice versa. Therefore high viscosity index oils are good quality oils for use in engine 
crankcase. The colour of lubricating oil is commonly accepted as an important criterion of quality of lubricating oil. Therefore the improvement of viscosity index and colour is a major step towards the reclamation of waste lubricating oil. However after reclamation some characteristic properties of lubricating oil has been changed and so to reuse it after proper treatment with additives may be a good approach.

Additives for lubricating oils are chemical compounds necessary to improve the operating characteristics of oil such as viscosity index (Polyisobutylane, methacrylate polymers etc), colour (Anthraquinons, Aliphate amines etc), pour point (Polymethacrylate, polyisobutylene etc.), oxidation stability (Phosphorous and Sulphur compounds, aromatic amines), foaming (Silicones, polymethyl siloxans etc), rust inhibition (High base additives, sulphonates etc.). (Larson and Larson, 1960)

Reclamation of waste lubricating oil by acid treatment with conc. sulphuric acid followed by adsorption with fuller's earth was carried out by (Bhuiyan et al, 1987) and others but reclamation with commercial sulphuric acid followed by adsorption with activated clay and its reuse through improvement of properties by the addition of different types of additives have not been investigated sufficiently so far.
Therefore the aim of the present work is to reclaim waste lubricating oil at optimum conditions for optimum yield and to develop the properties particularly viscosity index, pour point and colour of the reclaimed oil by application of different types of additives to make is applicable as a standard lubricant.

\section{Materials and Methods}

Waste lubricating oils were collected from different automobile garages and different types of additives such as Polymethacrylate, Polyisobutylene, and Anthraquinone etc. were procured from the local market.

In the reclamation process, after dehydration the waste oil was subjected to agitation with commercial sulphuric acid (10\% v/v) for 30 40 minutes at $40-45^{\circ} \mathrm{C}$. The contents were kept overnight for settling sludge. The supernatened oil was separated by decantation. Fuller's earth (10 gm Fuller's earth for every $100 \mathrm{ml}$ of acid treated oil) and lime (5 w/v $\%)$ were added to the oil and mixing was done by mechanical stirrer for about $1 \mathrm{hr}$. Temperature was maintained between $70-80^{\circ} \mathrm{C}$ to avoid oxidation of oil. The whole mass was then filtered through a filter cloth. Light colour oil was thus obtained. The experiment was repeated with different proportion of oil and acid with a view to obtaining optimum yield and the quality of the reclaimed oil. The effect of acid-oil ratio on the properties 
of waste lubricating oil was studied and shown in Table I.

The reclaimed oil was then blended with polymethacrylate and polyisobutylene additives at different proportion for improvement of viscosity index and pour point that are shown in Table IV and V respectively. To improve colour Anthraquinone additive was added to the reclaimed oil at different proportion and shown in Table VI.

TG analysis is a simple analytical technique that measures the weight loss of material as a function of temperature. This analysis was carried out by taking 0.3 to $0.4 \mathrm{gm}$ of reclaimed oil in a crucible of Thermo gravimetric Analyzer (TGA, Model TGA-50). The experiment was repeated with waste lubricating oil, fresh lubricating oil for comparative study and shown in Table 3. The colour of the reclaimed oil was determined by color comparator (Seta Lovibond colour comparator, ASTM D 1500-IP 196). The other physico-chemical properties of waste lubricating oil, reclaimed oil and fresh lubricating oil were also carried out by standard ASTM methods for comparative study and shown in shown in Table II.

\section{Results and Discussion}

Sulphuric acid treatment followed by adsorption on fuller's earth has profound effect on the properties of waste lubricating oil. The effect of acid-oil ratio on the viscosity index of reclaimed lubricating oil shown in Table I shows that gradual increase of acid-oil ratio, the viscosity index increases gradually and reaches the highest value of 93.43 at an acid-oil ratio of 10:100. Further increase of acid brings about a lowering of viscosity index. From Table I it is also seen that ash content and pour point decrease monoto

Table I : Effect of acid-oil ratio on the viscosity index, ash content, pour point and colour of reclaimed oil.

\begin{tabular}{c|c|c|c|c}
\hline Acid-oil ratio, v/v & Viscosity index & Ash content(\%) & Pour point $\left({ }^{0} \mathrm{C}\right)$ & Colour standard \\
\hline $2: 100$ & 86.10 & 0.105 & +10 & 7.0 \\
$4: 100$ & 87.82 & 0.085 & +8 & 6.5 \\
$6: 100$ & 89.41 & 0.053 & +7 & 6.5 \\
$8: 100$ & 91.24 & 0.032 & +5 & 6.0 \\
$10: 100$ & 93.43 & 0.015 & +2 & 5.0 \\
$12: 100$ & 92.82 & 0.0105 & +3 & 5.5 \\
$14: 100$ & 91.51 & 0.01 & +4 & 6.0 \\
\hline
\end{tabular}


Table II : Comparative properties of waste, reclaimed and fresh lubricating oil

\begin{tabular}{l|c|c|c|c|c}
\hline & $\begin{array}{c}\text { Waste } \\
\text { Lubricating Oil }\end{array}$ & $\begin{array}{c}\text { Reclaimed } \\
\text { oil }\end{array}$ & \multicolumn{3}{|c}{ Fresh lubricating } \\
oil
\end{tabular}

nously with the increase of acid-oil ratio.

Table I also shows that colour of reclaimed oil improves up to at acid-oil ratio 10:100. But with further increase of acid-oil ratio beyond 10:100, darkening of the oil reap- pears gradually which is probably due to charring of the oil because of higher concentration of acid. From Table-2, it is seen that after reclamation other physico-chemical properties of waste lubricating oil have been improved considerably.

Table III: Weight losing temperature (oc) of waste reclaimed reclaimed with additive and fresh lubricating oil.

\begin{tabular}{|c|c|c|c|c|c|c|c|}
\hline \multirow{2}{*}{$\begin{array}{c}\text { Sample \% } \\
\text { weight }\end{array}$} & \multirow{2}{*}{$\begin{array}{c}\text { Waste } \\
\text { lubricating } \\
\text { oil }\end{array}$} & \multirow{2}{*}{$\begin{array}{l}\text { Reclaimed } \\
\text { lubricating } \\
\quad \text { oil }\end{array}$} & \multirow{2}{*}{$\begin{array}{c}\text { Reclaimed } \\
\text { lube. oil } \\
\text { with } \\
\text { additive }\end{array}$} & \multirow{2}{*}{$\begin{array}{c}\text { Virgin } \\
\text { lubricating } \\
\text { oil }\end{array}$} & \multicolumn{3}{|c|}{ Fresh lubricating oil } \\
\hline & & & & & $\begin{array}{c}\text { SAE- } \\
30\end{array}$ & $\begin{array}{c}\text { SAE- } \\
40\end{array}$ & $\begin{array}{c}\text { SAE- } \\
60\end{array}$ \\
\hline $10 \%$ & 197.33 & 276.71 & 268.19 & 243.81 & 311.02 & 315.64 & 362.89 \\
\hline $20 \%$ & 254.53 & 312.04 & 308.53 & 288.47 & 339.36 & 341.08 & 391.61 \\
\hline $50 \%$ & 320.73 & 342.41 & 352.59 & 354.28 & 370.87 & 37.55 & 410.43 \\
\hline $70 \%$ & 386.42 & 405.21 & 420.62 & 386.30 & 440.72 & 435 & -453.25 \\
\hline $90 \%$ & 445.87 & -432.55 & 440.51 & 462.62 & 456.78 & 475 & -465.75 \\
\hline $98 \%$ & 533.30 & 449.05 & 493.36 & 573.06 & 489.57 & 550.23 & 473.78 \\
\hline $100 \%$ & 630.13 & 470.48 & & & 457.62 & 597.62 & 596.71 \\
\hline
\end{tabular}


Comparative TG analysis of waste lubricating oil, reclaimed lubricating oil, and reclaimed oil with additive and fresh lubricating oil was shown in table 3. From Table 3 , it is seen that weight loss pattern of reclaimed oil with additives is nearly close to that of fresh lubricating oil of SAE 30.
Polymethacrylate and Polyisobutylene and shown in Table IV and V. From Table IV and $\mathrm{V}$, it is clearly seen that viscosity index of reclaimed oil increases with the increase of addition of additives and reaches maximum at $1.2 \%$ (by weight of reclaimed oil). Pour point of reclaimed oil also decreases gradually with

Table IV: Effect of additive 1 on viscosity Index, pour point of reclaimed lubricating oil.

\begin{tabular}{l|c|c|c}
\hline Name of additive & $\begin{array}{c}\text { Quantity of additive } \\
\text { (\%wt, of reclaimed oil) }\end{array}$ & Viscosity index & Pour point $\left({ }^{\mathrm{O}} \mathrm{C}\right)$ \\
\hline & 0.0 & 93.43 & +2 \\
0.2 & 97.44 & -2.0 \\
Poly methacrylate & 0.4 & 101.23 & -5.0 \\
& 0.6 & 103.52 & -7.0 \\
& 0.8 & 105.83 & -8.5 \\
1.0 & 107.92 & -9.6 \\
& 1.2 & 109.75 & -10.5 \\
& 1.4 & 109.70 & -10.4 \\
\hline
\end{tabular}

Viscosity index of reclaimed lubricating oil has been improved by the addition the increase of addition of additives as of viscosity index improvers such as shown in Table IV and V.

Table V : Effect of additive 2 on viscosity Index, pour point of reclaimed oil.

\begin{tabular}{l|c|c|c}
\hline Name of additive & $\begin{array}{c}\text { Quantity of additive } \\
\text { (\%wt, of reclaimed oil) }\end{array}$ & Viscosity index & Pour point $\left({ }^{\mathrm{O}} \mathrm{C}\right)$ \\
\hline & 0.0 & 93.43 & +2 \\
0.2 & 97.39 & -1.5 \\
& 0.4 & 101.19 & -4.0 \\
& 0.6 & 102.30 & -6.0 \\
Poly isobutylene & 0.8 & 104.25 & -7.8 \\
& 1.0 & 106.46 & -9.4 \\
& 1.2 & 107.78 & -10.5 \\
& 1.4 & 107.40 & -10.6 \\
& 1.4 & 109.70 & -10.4 \\
\hline
\end{tabular}


Table VI: Effect of additive on colour of reclaimed oil.

\begin{tabular}{l|c|c}
\hline Name of additive & $\begin{array}{c}\text { Quantity of additive } \\
\text { (\%wt, of reclaimed oil) }\end{array}$ & Colour standard \\
\hline & 0.0 & 5.0 \\
& 0.05 & 5.0 \\
Anthraquinone & 0.15 & 4.5 \\
& 0.25 & 4.0 \\
& 0.50 & 5.0 \\
& 0.75 & 5.5 \\
\hline
\end{tabular}

The effect of additive (anthrquiuone) on colour of reclaimed oil was shown in table 6 . Colour was improved and best result was obtained with $0.25 \%$ (by wt. of reclaimed oil) addition of anthraquinone to reclaimed oil which assumes the same colour as that of fresh lubricating oil SAE 40.

\section{Conclusion}

The reclaimed oil obtained in the present investigation after $\mathrm{H}_{2} \mathrm{SO}_{4}$ washing, fuller's earth treatment and addition of different types of additives resembles the SAE 30 grade lubricating oil in terms of properties and is applicable as a standard lubricants. Such a reuse of waste lubricating oil, in addition to its economic effect, will help reduce environmental pollution.

\section{References}

Bhuiyan, T.A Haque, M. Naimul, Eusuf, M. (1987) Reclamation of used lubricating oils. Part I Improvement of viscosity index and colour with pure conc. Sulfuric Acid. $J$. Sci. Ind. Res. 22 (1-4): 61-67.

Encyclopedia of Science and Technology, Mc Graw-Hill Book company, Inc. Newyork, (1966) 7: 601-602

Evstafev, V.P. Kononova, E.A. Levin, Ya., Trofimova, G.L. Ivanova, O.A (2004) A New Dithiophposphate Additives for lubricating Oils, Journal of Chemistry and Technology of Fuels and Oils, 37: 427-431,

Gomez, M.E.G. Hildige, R.H. Leahy, J.J O'Reilly, T. Supple, B. Malone, M. (2004) Emmision and Performance Characteristics of Two Litre Toyota Diesel Van Operating One Esterified Waste Cooking Oil and Mineral Diesel Fuel, Journal of Evvirnomental Monitoring and Assessment, 65: 13-20.

Guthrie, V.B. (1960) Petroleum Products Handbook, 1st Ed. (Macraw - Hill Book Company,Inc. Newyork, 9-127 
Kalichevsky, V.A. Kabe, K.A. (1956) Petroleum Refining with Chemicals, Elsevier Publishing Company, London, 77-78

Kovalenko, K.V. Krivokhizha, S.V Rakaeva, G.B. (2007) Quality colntrol of petroleum oils with Additives, Journal of Chemistry and Technology of Fuels and Oils, 43: 64-69.

Larson, C.M. Larson, R. (1960) Additives for Petroleum Products, Petroleum products Handbook, 1st Edition, Mc Graw-Hill Book company, Newyork, 2: 48.
Mynin, V.N. Smirnova, E.B. Katesereva, O.V Kamyagin, E.A. Tertugov, G.V. (2004) Smirnov V.N, Treatment and Regeneration of Used Lube Oils with in Organic Membranes, Journal of Chemistry and Technology of Fuels and Oils, 40: 345-350

Pidgeon, D.G. Tester, H.E.(1929) J. Inst. Petrol Technology, 15: 91.

Received : June, 04, 2008;

Accepted : September 02, 2008 